\title{
Development of Digital-Based Learning Media in Sociolinguistics Courses in the Pandemic Era
}

\author{
Emasta Evayanti Simanjuntak ${ }^{1}$, Tangson R. Pangaribuan², Azhar Umar ${ }^{3}$, Trisnawati \\ Hutagalung ${ }^{4}$
}

\author{
1,2,3,4 Department of Indonesian Language Education, Faculty of Languages and Literature, Universitas Negeri \\ Medan, Medan, 20221, Indonesia \\ Email: evayantiemasta@gmail.com; tangson.rp@gmail.com; azharumar@gmail.com; \\ trisnawati.hutagalung@yahoo.co.id
}

\begin{abstract}
The rise of the Covid-19 virus affects all activities especially activities that need face-to-face. For this reason, the usage of digital is growing rapidly, including in teaching and learning process. Digital-based learning media need to be developed to increase the quality of learning especially in educational institutions during the pandemic. Prezi is a digital-based learning media that can develop various ideas in a narrative visual form. One of the courses in the Indonesian Language and Literature Education Study Program is Sociolinguistics which allows it to be presented using digital-based learning media, in this case Prezi. The purpose of this study was to describe the effectiveness of Prezi-based learning media in sociolinguistics courses at the Indonesian Language and Literature Education Study Program, Medan State University. The population in this study were all students of the 2019 Indonesian Language Education Study Program and the sample is 30 students. This study uses quantitative research methods in the form of experiments and descriptive research with the one group pre-test-post-test type. Student learning outcomes before using Prezi-based learning media in sociolinguistics courses get an average value of 70.2 with a standard deviation of 16.30 and a standard error of 2.9. After using Prezi-based learning media, the average score was 85.4 with a standard deviation of 9.32 and a standard error of 1.8. For this reason, the use of Prezi-based learning media is effectively used in sociolinguistic courses in the Indonesian Language and Literature Education Study Program.
\end{abstract}

Keywords: Prezi, Digital, Sociolinguistics, Pandemic.

\section{INTRODUCTION}

Education and technology are inseparable. The application of technology in education cannot be separated from the learning process which includes educators, students, and the learning environment that influence each other. The use of technology in education allows for more varied, easy and fun learning activities, including the use of media in learning, both at school and in higher education.

The use of technology as an integrated learning media is expected to make it easier to convey information and can also influence the learning process to be more effective both at school and in college. In higher education, learning media can be used as a component that can help lecturers or students in the learning process. For this reason, lecturers and students are expected to have sufficient understanding of learning media and how to use them. But so far, based on observations made at Medan State University, Faculty of Language and Arts, Department of Indonesian Language and Literature, it can be seen that most lecturers or students only use the same media in the learning process, so that boredom or disinterest arises. in study. And it can have an impact on not achieving learning objectives, for example in Sociolinguistic learning.

There are many types of active, creative and interesting learning media that can be used in the teaching and learning process, one of which is Prezi learning media. Daryanto (2016: 70) states that Prezi application-based learning media can be interpreted as a multimedia application used in the learning process, in terms of stimulating choices, feelings of attention, and 
willingness of students so that the learning process can be purposeful, occur and be controlled.

Some of the reasons behind this research are:

- lecturers or students only use existing learning media without looking for other media.

- The Prezi learning media has not been used effectively in the Indonesian Language and Literature Education Study Program, FBS Unimed

- There is a lack of interest in students participating in the learning process, because there is no interesting learning media, so that it has an impact on students' knowledge of the subject.

For this reason, this study aims to describe the development of digital-based learning media in sociolinguistic courses during the pandemic at the Indonesian Language and Literature Education FBS Unimed.

Several studies have shown that the use of learning media based on the Prezi application can improve the quality of learning for students. One of them is a study conducted by Ika Irawati (2018) entitled Development of Interactive Learning Materials Using the Prezi Application. The results of her research show that the Prezi interactive learning application is feasible to use. This is based on the results of the media expert's assessment of $95.00 \%$ (fit for use); material expert by $90.00 \%$ (feasible to use). In addition, the results of the student assessment questionnaire of $87.00 \%$ can increase student motivation in learning. This is in line with the research conducted by Neo Vidiasti (2019) entitled Development of Prezi Interactive Learning Media in Class XI Information and Communication Technology (ICT) Subjects at SMAN 1 Pakel. The results of the research show that the results of the three aspects include: (1) the media expert test was $91 \%$ and the material expert got a score of $82 \%$ (meets quality standards); (2) the application test obtained a score of $100 \%$ (fit for use); (3) small group trials obtained $76 \%$ and field trials obtained $77 \%$ (feasible to use). And the test results show that the learning media using Prezi interactive media is feasible to be used as an interactive learning media. The same thing also shows that Prezi is feasible to be used as a learning media, such as the research conducted by Surani and Dina Ampera (2017) entitled Development of Prezi Learning Media in The Subject of Making Patterns at the Early Vocational School of Galang Development Work. And the results of the research show that the design of Prezi learning media in subjects made this pattern successfully developed through several stages, namely 1) the results of the material expert assessment with a score of $83 \%$ with good criteria and the results of the media expert assessment with a score of $87.14 \%$ with very good criteria., 2) the results of group trial assessments: small group trials with a score of $63.3 \%$, medium group trials with a score of $79.25 \%$ with agreed criteria, and large group or field trials 89.25 with strongly agree criteria, 3 ) student effectiveness test with an average score of
$89.25 \%$ with criteria strongly agree and teacher effectiveness test with an average score of $93.33 \%$ with criteria strongly agree.

Thus, the design of Prezi learning media in subjects makes the pattern considered feasible to be used as a learning media design.

\section{THEORETICAL REVIEW}

\subsection{Learning Media}

The word media comes from the Latin, namely "medius" which literally means 'middle', 'intermediary' or 'introduction'. In Arabic the media is called 'wasail' the 'jama' form of 'wasilah', which is a synonym for "alwast" which also means 'middle'. The word 'middle' itself means being between two sides, so it is also referred to as 'intermediary' (wasilah) or who mediates the two sides (Munadi, 2013: 6). Furthermore, Munadi (2013: 7) defines learning media as anything that can convey and distribute messages from sources in a planned manner so as to create a conducive learning environment where the recipient can carry out the learning process efficiently and effectively.

\subsection{Prezi App}

Prezi was originally developed by a Hungarian architect named Somlai Fischer as an architectural visualization tool. Prezi is used to create presentations in linear or non-linear form, namely structured presentations as an example of linear presentations, or non-linear presentations. Daryanto (2016: 70) states that Prezi application-based learning media can be interpreted as a multimedia application used in the learning process, in terms of stimulating choices, feelings of attention, and willingness of students so that the learning process can be purposeful, occur and be controlled.

\subsection{Sociolinguistics}

Sociolinguistics examines the relationship between language and society, and links two fields that can be studied separately, namely the formal structure of language by linguistics and the structure of society by sociology (Wardhaugh 1984: 4; Holmes 1993: 1; Hudson 1996: 2). Sociolinguistics is an interdisciplinary science between sociology and linguistics, two fields of empirical science that are very closely related. Sociology is an objective and scientific study of humans in society, about institutions, and social processes that exist in society. Sociology seeks to find out how society came into being, lasted, and persisted. Sociolinguistics can be defined as the study of language in relation to society. 


\section{RESEARCH METHODOLOGY}

This research was designed with the Research and Development (R\&D) method. The research and development (R\&D) method according to Sugiyono (2015) is a research method used to produce certain products and test the effectiveness of these products. As the name suggests, research and development methods. The research referred to here is to test the Prezi Learning Media which is carried out in the Sociolinguistic KDBK learning process at the Indonesian Language and Literature Education Study Program FBS Unimed. The development in question is how to develop Prezi learning media in the Indonesian Language and Literature Education Study Program FBS Unimed after testing.

\section{RESEARCH RESULTS DISCUSSION}

AND

\subsection{Feasibility of Prezi in Its Utilization in Sociolinguistic Courses in the Pandemic Period in Indonesian Language and Literature Education Study Program}

The results of validation and assessment by material experts and media experts on each aspect of the overall assessment are determined by the average score of the respective criteria. The results of the study were analyzed to determine the feasibility of Prezi. The average percentage of the results of the assessment by material experts, media experts, lecturers' assessments as well as the results of individual trials, small group trials and limited field group trials assessed based on aspects and indicators of the assessment. The results of the aspects of the assessment obtained will be described as follows.

\subsubsection{Material Expert Validation Result Data}

Based on the results of the assessment of the feasibility aspect of the material content, the use of Prezi in the Sociolimguistics course during the pandemic was declared "Very Good" with a total average percentage of $85.6 \%$. The data from the validation of material experts on the feasibility of the content can be seen in Table 1 below.

The results of the validation by the validator above on the feasibility of the content show that the feasibility of the content of the learning media that has been developed includes very good criteria. This can be seen from the presentation feasibility assessment score according to material experts rated "Very Good" with an average total presentation of $85.9 \%$. The data from the validation of material experts on the feasibility of presentation can be seen in Table 2 .

Table 1. Prezi material expert assessment for content feasibility

\begin{tabular}{|c|c|c|c|}
\hline Sub Componen & Indicator & Average (\%) & Kriteria \\
\hline \multirow{3}{*}{$\begin{array}{l}\text { A. The suitability of the } \\
\text { material with the } \\
\text { Learning Outcomes }\end{array}$} & 1. Completeness of the material & 86 & Very Good \\
\hline & 2. Material breadth & 84 & Very Good \\
\hline & 3. Material depth & 84,5 & Very Good \\
\hline \multirow[t]{6}{*}{ B.Material Accuracy } & 4. Concept and definition accuracy & 85 & Very Good \\
\hline & 5. Data accuracy & 88 & Very Good \\
\hline & 6. Sample accuracy & 86 & Very Good \\
\hline & 7. Image accuracy & 87 & Very Good \\
\hline & 8. Accuracy of terms & 85,5 & Very Good \\
\hline & 9. Accuracy of symbols and icons & 84 & Very Good \\
\hline \multirow[t]{5}{*}{ C. Up-to-date material } & $\begin{array}{l}\text { 10. The suitability of the material with language } \\
\text { development }\end{array}$ & 85 & Very Good \\
\hline & $\begin{array}{llll}11 . & \text { Internet-based display using local } \\
\text { community Prezi }\end{array}$ & 86 & Very Good \\
\hline & 12. Examples and cases in everyday life & 88 & Very Good \\
\hline & 13. Pictures and illustrations in everyday life & 85 & Very Good \\
\hline & 14. using case examples found in everyday life & 85 & Very Good \\
\hline \multirow{2}{*}{$\begin{array}{ll}\text { D. } & \text { Encourages } \\
\text { Curiosity } & \end{array}$} & 15. Encourages Curiosity & 85 & Very Good \\
\hline & 16. Creating the ability to ask questions & 86 & Very Good \\
\hline
\end{tabular}

Table 2. Expert Assessment of Prezi Materials for Presentation

\begin{tabular}{|c|c|c|c|}
\hline Sub Componen & Indicator & Average (\%) & Criteria \\
\hline \multirow{2}{*}{$\begin{array}{l}\text { A. Presentation } \\
\text { Techniques }\end{array}$} & 1. Consistent systematic presentation & 86 & Very Good \\
\hline & 2. Concept sequence & 84 & Very Good \\
\hline \multirow{2}{*}{$\begin{array}{ll}\text { B. } & \text { Presentation } \\
\text { Support } & \\
\end{array}$} & 3. Examples of questions in each learning activity & 87 & Very Good \\
\hline & 4. Introduction & 84,5 & Very Good \\
\hline $\begin{array}{l}\text { C. Learning } \\
\text { Presentation }\end{array}$ & 5. Student Involvement & 88 & Very Good \\
\hline \multirow{2}{*}{$\begin{array}{l}\text { D. Coherence and } \\
\text { coherence of thinking } \\
\text { flow }\end{array}$} & $\begin{array}{l}\text { 6. Linkages between learning activities/sub-learning } \\
\text { activities }\end{array}$ & 86 & Very Good \\
\hline & 7. Integrity of meaning & 86 & Very Good \\
\hline
\end{tabular}


Table 3. Prezi Material Expert Assessment for Language Aspect

\begin{tabular}{l|l|c|c}
\hline \multicolumn{1}{c|}{ Sub Componen } & \multicolumn{1}{c|}{ Indicator } & Average (\%) & \multicolumn{1}{c}{ Criteria } \\
\hline \multirow{2}{*}{ A. Straightforward } & 1. The accuracy of sentence structure & 86,5 & Very Good \\
\cline { 2 - 4 } & 2. Sentence effectiveness & 85 & Very Good \\
\cline { 2 - 4 } & 3. Term Standard & 87 & Very Good \\
\hline B. Communicative & 4. Understanding of messages or information & 87,5 & Very Good \\
\hline $\begin{array}{l}\text { C. Dialogical and } \\
\text { interactive }\end{array}$ & 5. ability to motivate students & 85 & Very Good \\
\cline { 2 - 4 } $\begin{array}{l}\text { D. Compatibility with the } \\
\text { level of student } \\
\text { development }\end{array}$ & $\begin{array}{l}\text { 7. Conformity with the intellectual development } \\
\text { of students }\end{array}$ & 87 & Very Good \\
\cline { 2 - 4 } & $\begin{array}{l}\text { 8. Conformity with the level of emotional } \\
\text { development of students }\end{array}$ & 84 & Very Good \\
\hline $\begin{array}{l}\text { E. Conformity with the } \\
\text { rules }\end{array}$ & 9. Grammatical accuracy & 87 & Very Good \\
\hline F. Use of terms & 10. Consistency of use of terms & 87 & Very Good \\
\hline
\end{tabular}

Table 4. Prezi Design Expert Assessment

\begin{tabular}{l|c|c}
\hline Indicator & Average (\%) & Criteria \\
\hline 1. Effective and efficient learning media & 86 & Very Good \\
\hline 2. Reliable (part or all of the learning media can be reused) & 86 & Very Good \\
\hline 3. Maintainable (can be easily maintained/managed) & 87,5 & Very Good \\
\hline 4. Usability (easy to use and simple in operation) & 85,5 & Very Good \\
\hline $\begin{array}{l}\text { 5. The accuracy of selecting the type of application/ software/ tool/ for } \\
\text { development }\end{array}$ & 85 & Very Good \\
\hline 6. compatibility & 87 & \\
\hline 7. Easy program packaging & 86 & Very Good \\
\hline 8. Completeness of learning media & 86 & Very Good \\
\hline 9. Reusable & 86,5 & Very Good \\
\hline
\end{tabular}

The assessment of the language aspect according to the material expert is rated "Very Good" with a total average percentage of $86.4 \%$. The data from the material expert validation on the language aspect can be seen in Table 3.

Some suggestions from material validators are as follows:

- The display of the material must be attractive

- The content of the material should be more specific

- Fix grammar

\subsubsection{Data from the Validation of Learning Design Experts}

The results of the validation of learning media by learning media experts can be concluded that the learning media developed are in the "very good" criteria with a total average percentage of $86.1 \%$. The data from media expert validation can be seen in Table 4 below.

Some suggestions from media expert validators are as follows.

- Complete the table of contents on prezi

- Media included in prezi should be more attractive

Design experts considered that Prezi in its use in Sociolinguistics courses for students of the Indonesian Language and Literature Education Study Program during the pandemic that was developed had feasibility with an average score percentage of $86.1 \%$.

\subsection{Feasibility Test of Prezi Learning Media in Sociolinguistics Courses in the Pandemic Era}

Prior to the feasibility test of the Sociolinguistics course learning media using the statistical t test, the normality and homogeneity requirements were tested. The two test requirements are described in the following sections

\subsubsection{Normality Test Pre-test Results}

This study tested the normality of the research data using the Lilifors normality test. The following will describe the calculation of normality as follows.

Based on the table, it is obtained that $\mathrm{L}_{\text {count }}=0.1191$ using $=0.05$ and $\mathrm{N}=30$, then the critical value through the Liliefors test is obtained $\mathrm{L}_{\text {table }}=0.161$. Thus $\mathrm{L}_{\text {count }}<$ $\mathrm{L}_{\text {table }}(0.1191<0.161)$. This proves that the pre-test data is normally distributed, shown in Table 5.

\subsubsection{Post-test Result Normality Test}

To test the normality of the post-test results, the Liliefors test can be used and the calculations can be seen in the appendix. The following Table 6 shows the normality of the post-test results.

Based on the Table 7 , it is obtained that $\mathrm{L}_{\text {count }}=$ 0.0928 using $=0.05$ and $\mathrm{N}=34$, then the critical value through the Liliefors test is obtained $\mathrm{L}_{\text {table }}=0.161$. Thus $\mathrm{L}_{\text {count }}<\mathrm{L}_{\text {table }}(0.0928<0.161)$. This proves that the posttest data is normally distributed. 
Table 5. Normality Test of Student Ability Results in Sociolinguistics Before Using Prezi

\begin{tabular}{c|c|c|c|c|c|c|c|c}
\hline $\mathbf{X}_{\mathbf{i}}$ & $\mathbf{F}_{\mathbf{i}}$ & $\mathbf{F}_{\mathbf{k u m}}$ & $\mathbf{Z}_{\mathbf{i}}$ & $\mathbf{F}\left(\mathbf{Z}_{\mathbf{i}}\right)$ & $\mathbf{S}\left(\mathbf{Z}_{\mathbf{i}}\right)$ & $\mathbf{F}\left(\mathbf{Z}_{\mathbf{i}}\right)-\mathbf{S}\left(\mathbf{Z}_{\mathbf{i}}\right)$ & $\mathbf{L}_{\text {count }}$ & $\mathbf{L}_{\text {table }}$ \\
\hline 50 & 1 & 1 & $-2,0359$ & 0,0209 & 0,0333 & 0,0125 & 0,1191 \\
\hline 52 & 1 & 2 & $-1,8344$ & 0,0333 & 0,0667 & 0,0334 \\
\hline 55 & 1 & 3 & $-1,5320$ & 0,0628 & 0,1000 & 0,0372 \\
\hline 58 & 1 & 4 & $-1,2296$ & 0,1094 & 0,1333 & 0,0239 \\
\hline 60 & 3 & 7 & $-1,0280$ & 0,1520 & 0,2333 & 0,0814 \\
\hline 63 & 1 & 8 & $-0,7257$ & 0,2340 & 0,2667 & 0,0326 \\
\hline 70 & 4 & 12 & $-0,5241$ & 0,3001 & 0,2667 & 0,0334 \\
\hline 72 & 2 & 14 & $-0,0202$ & 0,4920 & 0,4000 & 0,0920 \\
\hline 74 & 1 & 16 & 0,1814 & 0,5720 & 0,4667 & 0,1053 \\
\hline 75 & 4 & 21 & 0,3830 & 0,6491 & 0,5333 & 0,1158 \\
\hline 78 & 1 & 22 & 0,6854 & 0,7534 & 0,7000 & 0,0534 \\
\hline 80 & 4 & 23 & 0,7862 & 0,7841 & 0,7667 & 0,0174 \\
\hline 85 & 1 & 28 & 0,9877 & 0,8384 & 0,9000 & 0,0616 \\
\hline 86 & 1 & 29 & 1,4909 & 0,9179 & 0,9333 & 0,0155 \\
\hline
\end{tabular}

Table 6. Normality Test of Student Ability Results in Sociolinguistics After Using Prezi

\begin{tabular}{|c|c|c|c|c|c|c|c|c|}
\hline $\mathbf{X}_{\mathbf{i}}$ & $F_{i}$ & $\mathbf{F}_{\text {kum }}$ & $\mathbf{Z}_{\mathbf{i}}$ & $\mathbf{F}\left(\mathbf{Z}_{\mathbf{i}}\right)$ & $\mathbf{S}\left(\mathbf{Z}_{\mathrm{i}}\right)$ & $\mathbf{F}\left(\mathbf{Z}_{\mathbf{i}}\right)-\mathbf{S}\left(\mathbf{Z}_{\mathbf{i}}\right)$ & $\mathbf{L}_{\text {count }}$ & $\mathbf{L}_{\text {table }}$ \\
\hline 77 & 1 & 1 & $-2,6065$ & 0,0046 & 0,0333 & 0,0288 & 0,0928 & 0,161 \\
\hline 80 & 3 & 4 & $-1,6756$ & 0,0469 & 0,1333 & 0,0864 & & \\
\hline 82 & 1 & 5 & $-1,0550$ & 0,1457 & 0,1667 & 0,0210 & & \\
\hline 83 & 1 & 6 & $-0,7447$ & 0,2282 & 0,2000 & 0,0282 & & \\
\hline 84 & 3 & 9 & $-0,4344$ & 0,3320 & 0,3000 & 0,0320 & & \\
\hline 85 & 4 & 13 & $-0,1241$ & 0,4506 & 0,4333 & 0,0173 & & \\
\hline 86 & 7 & 20 & 0,1862 & 0,5738 & 0,6667 & 0,0928 & & \\
\hline 87 & 2 & 22 & 0,4965 & 0,6902 & 0,7333 & 0,0431 & & \\
\hline 88 & 4 & 26 & 0,8068 & 0,7901 & 0,8667 & 0,0766 & & \\
\hline 90 & 4 & 30 & 1,4273 & 0,9233 & 1,0000 & 0,0767 & & \\
\hline
\end{tabular}

Table 7. Research Data Normality Test

\begin{tabular}{|c|c|c|c|c|}
\hline No. & Class & L. Count $\left(\mathbf{L}_{\mathbf{o}}\right)$ & $\mathbf{L}_{\text {tabel }}$ & Status \\
\hline 1 & Pre-test & 0,1191 & 0,161 & Normal \\
\hline 2 & Post-test & 0,0928 & 0,161 & Normal \\
\hline
\end{tabular}

\subsection{Homogeneity Test}

The homogeneity of variance test was carried out to test the similarity of the variables. To test the homogeneity of the pretest and posttest used the formula:

$$
F=\frac{s_{1}}{S_{2}}
$$

Keterangan :

$$
\begin{aligned}
& \begin{array}{l}
S_{1=} \text { biggest variant } \\
S_{2=\text { smallest variant }}
\end{array} \\
& S_{X}^{2}=\sqrt{\frac{N \cdot \sum x^{2}-\left(\sum x\right)^{2}}{N(N-1)}}=\sqrt{\frac{29.4435236-(2106)^{2}}{30(30-1)}}=\sqrt{\frac{128621844-4435236}{870}}=16,3 \\
& S_{X}^{2}=\sqrt{\frac{N \cdot \sum y^{2}-\left(\sum y\right)^{2}}{N(N-1)}}=\sqrt{\frac{29.6563844-(2562)^{2}}{30(30-1)}}=\sqrt{\frac{190351476-6563844}{870}}=9,32 \\
& F=\frac{S_{\text {big }}}{S_{\text {small }}} \\
& F=\frac{16.3}{9.32}=1.74
\end{aligned}
$$

Then $\mathrm{F}_{\text {count }}=1.74$

Find $F_{\text {table: first find }} \mathrm{df}(\mathrm{n} 1)=\mathrm{k}-1=2-1=1$ and $\mathrm{df}(\mathrm{n} 2)=\mathrm{n}-\mathrm{k}=60-2=58$. Then check the $\mathrm{F}_{\text {table }}$ with a significant 0.05 then $\mathrm{F}_{\text {table }}=3.99$ 
Table 8. Research Homogeneity Test

\begin{tabular}{|c|c|c|c|c|}
\hline No & Group & Fcount & F tabel & Status \\
\hline 1 & Pre-Test & \multirow{2}{*}{1,74} & 3,99 & $\begin{array}{c}\text { It appears that } \mathrm{F}_{\text {count }}<\mathrm{F}_{\text {table }} \text { So that the variables } \mathrm{x} \\
\text { and y come from a homogeneous population }\end{array}$ \\
\hline 2 & Post-Test & &
\end{tabular}

\subsection{Hypothesis testing}

After testing for normality and homogeneity, it is known that the data before and after treatment are normally distributed and have the same variance (homogeneous). Thus, hypothesis testing is carried out using the $\mathrm{t}$ statistical test (difference test). Before calculating, it is better to explain the average, standard deviation and standard error of the two variables from the results of the pre test and post test.

Hypothesis testing was conducted to determine whether $H_{0}$ was accepted or rejected. In other words, if $H_{0}$ is rejected, it means $H_{a}$ is accepted. The following is hypothesis testing using the " $\mathrm{t}$ " test

a. Post-test Results

$$
\begin{aligned}
& \mathrm{M}_{\mathrm{y}}=85,4 \\
& \mathrm{SD}_{\mathrm{y}}=9,32 \\
& \mathrm{SE}_{\mathrm{my}}=1,8
\end{aligned}
$$

b. Pre-test Results

$$
\begin{aligned}
& \mathrm{M}_{\mathrm{x}}=70,2 \\
& \mathrm{SD}_{\mathrm{x}}=16,30 \\
& \mathrm{SE}_{\mathrm{mx}}=2,9
\end{aligned}
$$

From these data, the standard error of the two results is obtained, namely

$$
\begin{aligned}
S E_{M x-M y} & =\sqrt{S E_{M y}+S E_{M x}} \\
& =\sqrt{1,8+2,9} \\
& =\sqrt{4,71} \\
& =2,17
\end{aligned}
$$

Then continue withonly test " $t$ " with the following formula :

$$
\begin{aligned}
t_{o} & =\frac{M_{y}-M_{x}}{S E_{M_{1}-M_{2}}} \\
\mathrm{t}_{\mathrm{o}} & =\frac{85,4-70,2}{2,17} \\
\mathrm{t}_{\mathrm{o}} & =\frac{15,2}{2,17} \\
\mathrm{t}_{\mathrm{o}} & =7,0
\end{aligned}
$$

Furthermore, it was obtained $t_{\text {count }}=7.0$ then consulted with the $\mathrm{t}_{\text {table }}$ significant level $5 \%$ with $\mathrm{df}=\mathrm{N}$ $1=30-1=33$ obtained significant level $5 \%=1.69$. Because t0 obtained is greater than ttable ie 7.0> 1.69 then $H a$ is accepted.

\section{CONCLUSION}

Based on the results of the research that has been done, it is shown that Prezi-based learning media is effectively used. Student learning outcomes before using Prezi-based learning media in sociolinguistics courses get an average value of 70.2 with a standard deviation of 16.30 and a standard error of 2.9. After using prezi-based learning media, the average score was 85.4 with a standard deviation of 9.32 and a standard error of 1.8 .

Therefore, based on the results of hypothesis testing, it is proven that Prezi has a positive effect on improving students' abilities in sociolinguistic courses. The existence of a significant difference in the results of the pretest and posttest shows that using Prezi has a positive effect on student learning outcomes of the Indonesian Language and Literature Education Study Program in the sociolinguistic course.

\section{REFERENCES}

[1] Daryanto (2016). Media Pembelajaran. Yogyakarta: Gava Media

[2] Irawati, Ika. (2018). Pengembangan Materi Pembelajaran Interaktif dengan Menggunakan Aplikasi Prezi.Jurnal Pendidikan Bahasa: Vol.8 No.1 Hal. 19-24

[3] Munadi, Yudhi (2013). Media Pembelajaran. Jakarta Selatan: REFERENSI

[4] Sugiyono (2017). Metode Penelitian Pendidikan (Pendekatan Kuantitatif, Kualitatif dan R\&D). Bandung: Alfabeta

[5] Surani, dan Dina Ampera (2017). Pengembangan Media Pembelajaran PreziPada Mata Pelajaran Membuat Pola Di SMK Awal Karya Pembangunan Galang.Jurnal Pendidikan dan Teknologi Kejuruan: Vol. 19, No.1, Hal. 13-18

[6] Vidiasti, Neo (2019). Pengembangan Media Pembelajaran Interaktif PreziPada Mata Pelajaran Teknologi Informasi Dan Komunikasi (TIK) Kelas XI Di SMAN 1 Pakel. JOEICT: Vol.3 No.1 Hal. 88-94 